\title{
MAPEAMENTO GEOMORFOLÓGICO DA ÁREA DE INFLUÊNCIA DO ESCUDO SUL-RIO-GRANDENSE NO MUNICÍPIO DE PELOTAS
}

\author{
Moisés Ortemar Rehbein ${ }_{1}$ \\ Danilo da Silva Dutra ${ }^{2}$
}

\begin{abstract}
Resumo: Este trabalho objetiva o mapeamento geomorfológico da área de influência do Escudo Sul-Rio-Grandense no município de Pelotas, a partir de revisão bibliográfica, organização de banco de dados geográficos, trabalhos de campo, cartografias de padrões morfológicos e morfogenéticos do relevo. Mapearam-se colinas, morrotes e morros de diferentes litologias do Batólito de Pelotas, cabeceiras de drenagem com hollows e planícies aluviais. Os processos de formação do relevo resultam da ação plúvio-fluvial orientada por controles estruturais e condicionada por mudanças climáticas, com redefinições de níveis de base da rede de drenagem e intensificação de processos morfogenéticos. Na área se observaram evidências de processos erosivos laminares, solapamentos de taludes, assoreamentos e depósitos de inundações fluviais, resultantes de alterações hidrogeomorfológicas por ação antrópica. Os dados do trabalho trazem importantes contribuições para o mapeamento geomorfológico do município de Pelotas/RS, enquanto instrumento para educação ambiental.
\end{abstract}

Palavras chave: Cartografia Geomorfológica; Morfologias do relevo; Morfogêneses do relevo, Morfodinâmicas.

\section{GEOMORPHOLOGICAL MAPPING OF THE SUL-RIO- GRANDENSE SHIELD INFLUENCE AREA IN THE MUNICIPALITY OF PELOTAS}

\begin{abstract}
This work aims to the geomorphological mapping of the Sul-RioGrandense Shield influence area in the municipality of Pelotas, from bibliographic review, geographic database organization, fieldwork and cartography of morphological and morphogenetic patterns relief. Were mapped hills and mounds from different lithologies of Pelotas Batholith, headwaters with hollows and alluvial plains. The processes of relief formation result from pluvial-fluvial action guided by structural controls and conditioned by climate changes, with redefinitions of base levels of the drainage network and intensification of morphogenetic processes. In the area, evidences of laminar erosive processes, riverbank erosion, silting and river flood deposits resulting from hydrogeomorphological changes by anthropic action were observed. The work data brings important contributions to the geomorphological

\footnotetext{
${ }^{1}$ Professor do Departamento de Geografia do Instituto de Ciências Humanas da Universidade Federal de Pelotas (UFPel).moisesgeoufpel@gmail.com

2 Universidade Federal do Rio Grande do Sul - UFRGS/ Doutorando do Programa de Pós-Graduação em Geografia - POSGea
} 
mapping of the municipality of Pelotas / RS, as an instrument for environmental education.

Keywords: Geomorphological Cartography; Relief morphologies; Relief morphogenesis, Morphodynamics.

\section{INTRODUÇÃO}

O mapeamento geomorfológico "se constitui num dos principais métodos e produtos da pesquisa geomorfológica" (RODRIGUES, 1997, p. 88). A existência de um plano de informações representado pelo mapeamento geomorfológico contribui na elucidação de processos erosivos e deposicionais, assim como, mediante combinações com outros mapeamentos temáticos, viabiliza a elaboração de cenários ambientais, como áreas de riscos a inundação, por exemplo (ARGENTO, 2009).

Este trabalho faz parte do projeto de mapeamento geomorfológico do município de Pelotas/RS, o qual visa contribuir com informações morfológicas do relevo e seus processos evolutivos no município.

Cabe-se ressaltar que outros trabalhos já abordam alguns dados cartográficos do relevo de Pelotas, dos quais se destacam Cunha e Silveira (1996), de caráter pedológico e o de Marth et al. (2008), de ênfase geológica. Demais contribuições resultam do levantamento de atributos do relevo para a análise de bacias hidrográficas, como Simon (2007), por exemplo.

O projeto de mapeamento geomorfológico do município de Pelotas se desenvolve a partir de duas frentes de pesquisa, determinadas em função das distintas morfogêneses, morfologias e morfodinâmicas de unidades morfoestruturais de relevo que ocorrem no município, áreas do Escudo Sul-Rio-Grandense e da porção emersa da Bacia Sedimentar de Pelotas, áreas da Planície Costeira do RS.

Este artigo apresenta o mapeamento geomorfológico da área de influência do Escudo Sul-Rio-Grandense no município de Pelotas. A área de influência do Escudo é de $898,38 \mathrm{~km}^{2}$, correspondendo a aproximadamente $55,8 \%$ da área total do município (Figura 1). 
Figura 1: Área do Escudo Sul-Rio-Grandense no município de Pelotas/RS.

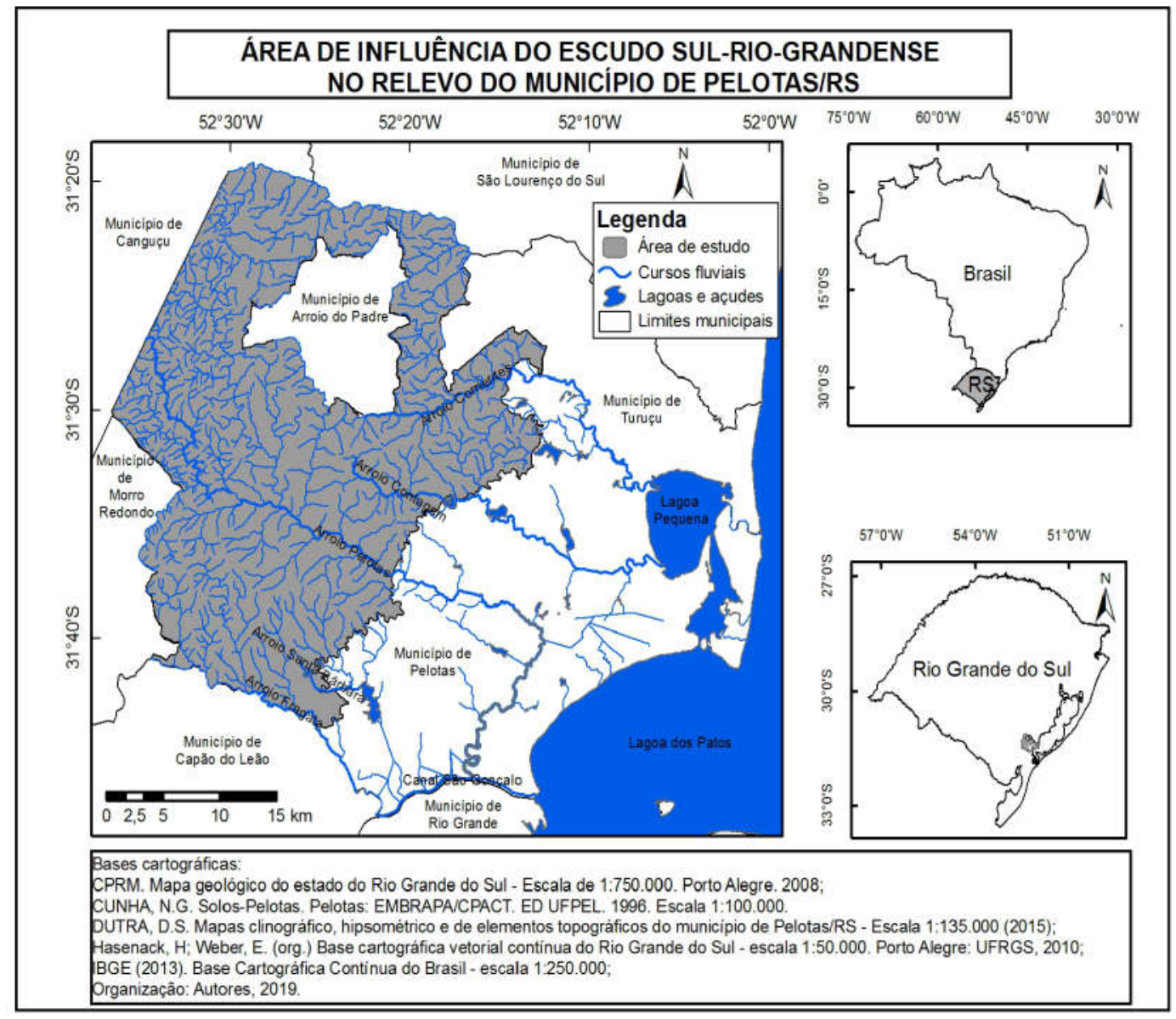

Fonte: Os autores.

Nessa área se desenvolve uma rede hidrográfica de significativa importância ecológica e social para Pelotas e municípios limítrofes, da qual cabem destacar as nascentes e seções fluviais dos arroios Pelotas, Santa Bárbara, Fragata, Corrientes, Contagem e do canal São Gonçalo, usados para abastecimento urbano e rural (Figura 1).

Os resultados dessa pesquisa dão base ao desenvolvimento de projetos de ensino e extensão, como o "Descobrindo a Geomorfologia e Hidrogeografia do município de Pelotas/RS: conhecer, sensibilizar, preservar".

Esses projetos têm a intenção de divulgação e popularização da Geomorfologia e Hidrogeografia junto à comunidade universitária e escolar (professores e alunos da rede de ensino básico) do município de Pelotas e municípios vizinhos, que compartilham bacias hidrográficas, através de oficinas pedagógicas e trabalhos de campo. Os projetos preveem atividades de reconhecimento, problematização e valorização das características e processos dos relevos dessas áreas, em interfaces às análises de impactos ambientais, possíveis medidas mitigadoras, de recuperação de áreas degradadas e preservação ambiental. 


\section{MATERIAL E MÉTODOS}

$\mathrm{Na}$ atividade de mapeamento geomorfológico se seguiram definições taxonômicas para a cartografia do relevo apresentadas em ROSS (1992), que traz, entre outras fundamentações, as contribuições de Guerasimov (1946), Mecerjakov (1968) e Demek et al (1972).

Considerando-se as dimensões da área de estudo e a escala gráfica de representação, o trabalho se desenvolveu na perspectiva de inventariação e cartografia dos padrões de formas semelhantes do relevo, considerando-se aspectos morfológicos e respectivas morfogêneses, terceiro táxon da proposta de ROSS (1992).

A organização da legenda e do seu conteúdo segue as proposições da União Geográfica Internacional (UGI) apresentadas em Demek et al (1972) e Klimaszewski (1982) e adaptadas por Rehbein (2011), a partir da inserção de abordagens morfodinâmicas para fins de aplicação do mapeamento geomorfológico na análise de impactos ambientais.

A pesquisa se desenvolveu a partir das seguintes etapas:

a) Revisão bibliográfica - compreende a sistematização de informações existentes sobre a geologia, pedologia, hidrografia, climatologia e dos usos e coberturas da terra da área de estudo.

b) Estruturação de um banco de dados geográficos - compreende a seleção de bases matriciais e vetoriais georreferenciadas e o seu recorte espacial para área de estudo, constituindo um Sistema de Informações Geográficas (SIG).

Constituem planos de informações: b.1 Limite municipal de Pelotas 1:250.000 (IBGE, 2013); b.2 Base cartográfica - curvas de nível, pontos cotados, hidrografia e sistema viário - 1:50.000 (HASENACK \& WEBER, 2010); b.3 Anaglifos de fotografias aéreas - 1:40.000 (FAB/ ALM, 1953); b.4 Imagens de Satélite Landsat 5 TM (Bandas 1 a 5) - resolução espacial de 30 metros (INPE, 2015); b.5 Mapa dos solos do município de Pelotas - 1:100.000 (CUNHA e SILVEIRA, 1996) e Mapa geológico do RS (CPRM, 20083). Para os diferentes planos de informações se adotou a projeção UTM (fuso 22) e o datum SIRGAS2000.

c) Mapeamento geomorfológico - esta etapa consiste na elaboração de documento cartográfico de síntese, resultante da sobreposição de cartografias de padrões morfológicos e morfogenéticos do relevo e indicação de respectivas morfodinâmicas.

c.1) Cartografia de padrões morfológicos do relevo: este documento resulta do processamento dos materiais do bando de dados geográficos para a geração de novos planos de informações, tais como: Imagens anaglifos de fotografias aéreas; Modelo Numérico do Terreno; Mapa clinográfico, hipsométrico, de elementos topográficos do relevo e trabalhos de campo.

Para geração de imagens anaglifos se seguiram as orientações de Santos e Dias (2011). A metodologia dos autores resulta na aplicação de estereoscopia em pares de fotografias aéreas parcialmente sobrepostas, em meio digital, a partir do

\footnotetext{
${ }^{3}$ O mapa geológico do estado do RS é um produto derivado do Projeto Geologia do Brasil ao Milionésimo, executado pela Superintendência Regional de Porto Alegre. No contexto da área de influência do Escudo Sul-Rio-Grandense no município de Pelotas, o mapa geológico do RS possui como fontes cartográficas Favilla et al. (2000) na escala de 1:250.000 e Phillip (1998), que apresenta a geologia do Batólito de Pelotas. A síntese geológica das seções estudadas por Phillip (1998), como a seção Pelotas, Canguçu e Pinheiro Machado, baseia-se em um compilado de levantamentos e cartografias desde a escala de $1: 25.000$.
} 
uso de óculos 3D. De modo a cobrir a área de estudo, utilizaram-se às faixas de voo 08 (fotografias 22 e 23), 09 (fotografias 64 e 65), 10 (fotografias 103 a 114), 11 (fotografias 117 a 132), 12 (fotografias 161 a 177), 13 (179 a 194), 13A (96 a 98) e 14 (16 a 23), registradas pela Força Aérea Brasileira (FAB) no ano de 1953, disponibilizadas pela Agência de Desenvolvimento da Lagoa Mirim (ALM) e digitalizadas (com resolução de $300 \mathrm{dpi}$ ) e referenciadas pelo Laboratório de Geotecnologias da UFPel.

A construção do Modelo Numérico do Terreno resulta da interpolação de curvas de nível altimétricas de equidistâncias de $20 \mathrm{~m}$, através de modelagem por grade triangular. Do Modelo Numérico do Terreno se elaboraram os mapas clinográfico e hipsométrico do município. O primeiro mapa consistiu no agrupamento de dados em classes de declividades menores que $2 \%$, entre 2 a $4,99 \%, 5$ a 9,99\%, 10 a 19,99\%, 20 a 29,99\%, 30 a 39,99\% e maiores que $40 \%$ e o segundo em intervalos altimétricos de $20 \mathrm{~m}$.

As classes de declividades foram definidas a partir de intervalos clinográficos na caracterização de fases de relevo plano, suave ondulado, ondulado e fortemente ondulado, conforme EMBRAPA SOLOS (2013) e de intervalos consagrados nos estudos de capacidade de uso/ aptidão agrícola e valores críticos da geotecnia, indicativos do vigor dos processos erosivos e inundações, conforme Ross (1994).

Esses dois mapas, sobrepostos às imagens anaglifos, possibilitaram a vetorização de elementos topográficos, como divisores d'água, rupturas de declive e talvegues e, desse modo, a delimitação de padrões morfológicos de relevo e da área de influência do Escudo no município de Pelotas/RS. As definições das morfologias do relevo se pautaram em conceitos apresentados em Guerra \& Guerra (1997), Florenzano (2008) e IBGE (2009), considerando-se parâmetros morfográficos e morfométricos para colinas, morrotes, morros, cabeceiras de drenagem com formação de hollows e planícies.

Os trabalhos de campo consistiram em atividades in loco de reconhecimento e registros fotográficos dos diferentes padrões morfológicos cartografados e contaram com o apoio de Sistema de Posicionamento Global (GPS). Os campos foram realizados nas datas de 28/01; 29/03; 30/03 e 09/04 de 2016, após ocorrências pluviométricas, a fim de melhores observações das morfodinâmicas do relevo.

c.2) Cartografia de padrões morfogenéticos do relevo: este documento resulta da reorganização dos padrões morfológicos de relevo mapeados, conforme sobreposição de planos de informações litoestratigráficas (CPRM, 2008) e tipos de solos (CUNHA e SILVEIRA, 1996). Nos trabalhos de campo, procurou-se observar os aspectos texturais e estruturais das litoestratigrafias e solos, a partir de características visuais e táteis de materiais expostos em áreas de cortes para estradas e mineração e em áreas de afloramentos rochosos, próximas cabeceiras de drenagem.

c.3) Morfodinâmicas: resultam descrições de observações realizadas nos trabalhos de campo de formas de processos atuais (erosivas e deposicionais) em vertentes de diferentes morfologias, morfogêneses e usos e coberturas da terra.

Realizou-se o mapeamento de usos e coberturas da terra por meio de classificação digital supervisionada, pelo método da máxima verossimilhança, a partir de composição colorida 453 (RGB) de imagens Landsat 5 TM, de 28 de outubro de 2011, obtidas no site do Instituto Nacional de Pesquisas Espaciais (INPE). Seguindo-se chave de classificação do IBGE (2013), na área de estudo 
identificaram-se 5 classes de usos e coberturas: áreas de vegetação natural florestal, campestre, descoberta/ solo desnudo, água e silvicultura.

\section{RESULTADOS}

\section{PADRÕES MORFOLÓGICOS E MORFOGENÉTICOS DO RELEVO}

Na área de influência do Escudo Sul-Rio-Grandense no município de Pelotas foram identificados e mapeados seis padrões de formas semelhantes de relevo: em colinas, morrotes, morros, cabeceiras de drenagens com formações de hollows, planícies alveolares e fluviais (Figura 2 e 3 ).

As colinas, morrotes e morros compreendem superfícies de dissecação de unidades litológicas do Batólito de Pelotas. Conforme Fragoso Cesar et al., (1986), um complexo plutônico, multi intrusivo e polifásico, resultante de uma longa evolução geológica marcada por um somatório de distintos processos tectônicos. De acordo com Philipp, Nardi \& Bitencourt (2000), o Batólito tem sua evolução e posicionamento relacionados ao Ciclo Brasiliano (750-550 Ma).

Compreende suítes granitoides, sendo identificadas, também, exposições de rochas ígneas básicas e septos de metamorfismos encaixantes. Os granitoides foram afetados, ao decorrer de suas evoluções até a estruturação definitiva do Batólito, por notórios eventos de deformação, zonas de cisalhamento dúctil e rúptildúctil de escala continental, com extensão de dezenas de quilômetros por centenas de metros de espessuras, até zonas subverticais estreitas, com espessuras métricas a decamétricas (PHILIPP, NARDI \& BITENCOURT, 2000).

$\mathrm{Na}$ área do Escudo no município são encontradas quatro unidades litológicas do Batólito de Pelotas: Suíte Intrusiva Dom Feliciano, Fácies Cerro Grande e Fácies Serra do Herval; Granito Arroio Moinho e Complexo Granito-Gnáissico Pinheiro, Metagranitóides Foliados (Pinheiro Machado) (CPRM, 2008). 
Figura 2: Mapa dos padrões de formas semelhantes do relevo da área de estudo.

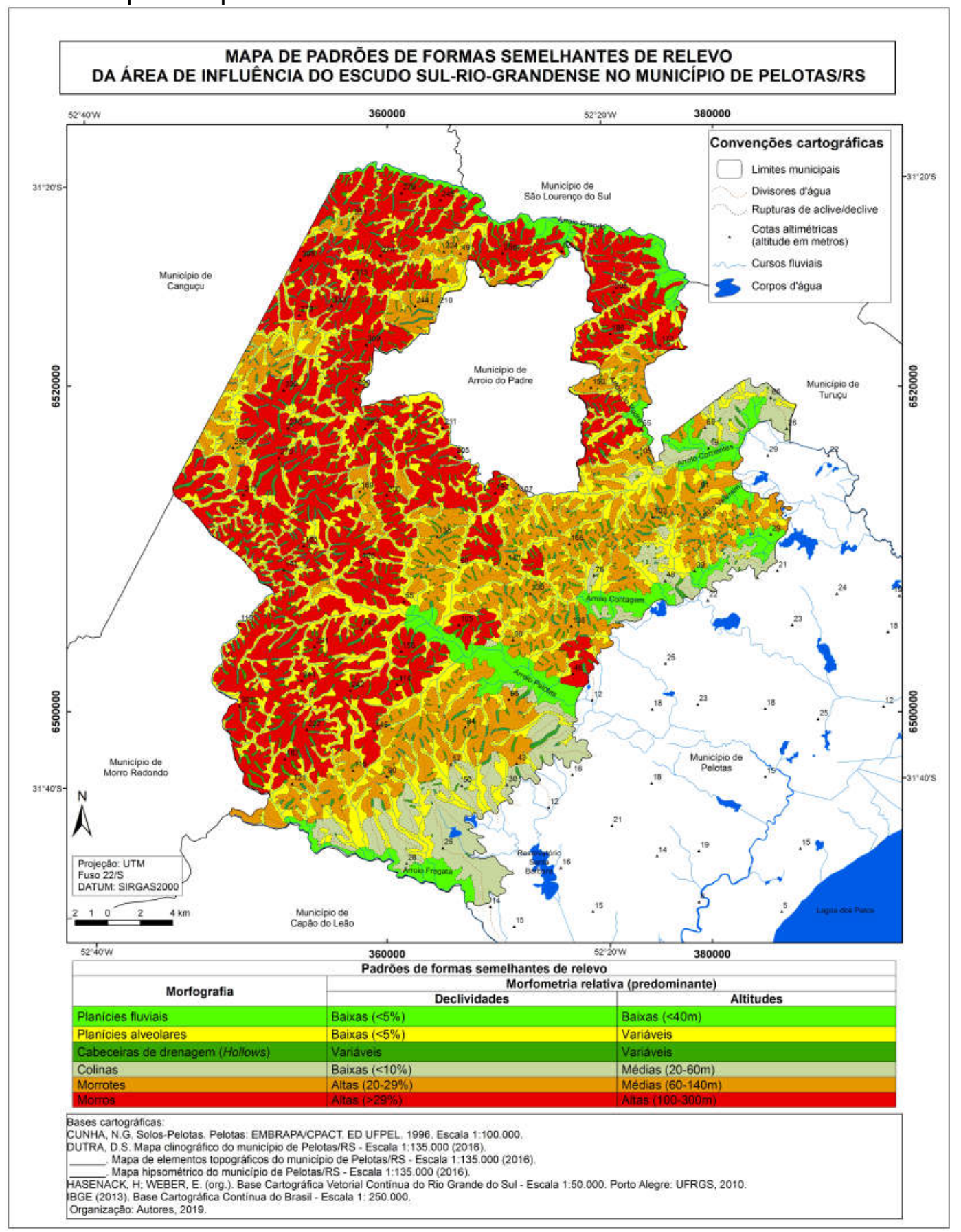

Fonte: Os autores.

Por sua vez, as áreas de cabeiras de drenagem com formação de hollows, planícies alveolares e fluviais compreendem superfícies de acumulação, atreladas às formações da Bacia Sedimentar de Pelotas e da Planície Costeira do RS. A gênese da Bacia de Pelotas é resultado da abertura do oceano Atlântico Sul, em virtude de esforços extensionais do continente Gondwana, quando da separação entre a América do Sul e a África há aproximadamente $65 \mathrm{Ma}$ (MENEGAT et al., 1998). 
Figura 3: Distribuição (\%) dos padrões de formas semelhantes do relevo na área de estudo.

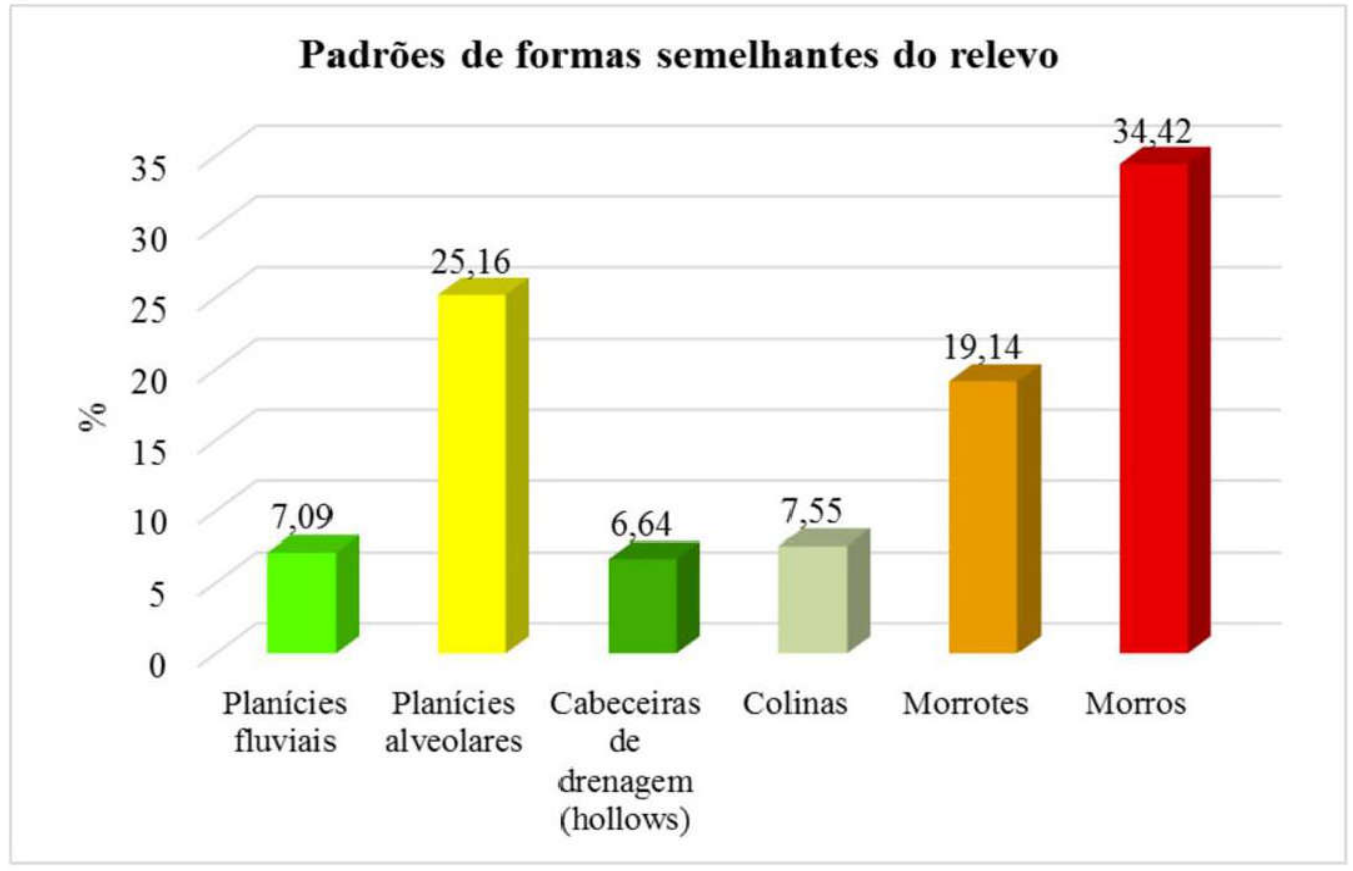

Fonte: Os autores.

Após a abertura do oceano Atlântico, no contexto de formação da Bacia de Pelotas, culminou o condicionamento para a evolução da Planície Costeira do RS que, conforme Tomazelli e Villwock (2000), um amplo sistema de leques aluviais resultante da dissecação das litologias do Escudo, somado ao acréscimo lateral de quatro sistemas de deposição do tipo "Laguna-Barreira".

\section{COLINAS, MORROTES E MORROS}

O padrão de relevo em colinas compreende superfícies transicionais entre a área de influência do Escudo e a Planície Costeira do RS no município de Pelotas. Caracterizam-se por segmentos de topos amplos, suave-convexos, vertentes de comprimentos de rampa notórios, predominantemente de baixas declividades, entre 2 a 9,99\%, e altitudes entre 20 a $60 \mathrm{~m}$. As colinas ocupam 67,87 $\mathrm{km}^{2}$ da área de estudo e compreendem superfícies de transição, especialmente, entre morrotes e planícies, com estas, através de suaves rupturas de declives.

O padrão de relevo em morrotes apresenta topos convexos e vertentes de declividades relativamente altas, entre 20 a 29,99\%, e altitudes entre 60 a 140m. Os morrotes ocorrem enquanto superfícies transicionais, delimitados por notórias rupturas de declives, entre morros e colinas. Ocupam 171,92 km².

O padrão de relevo em morros apresenta topos convexos, de geometrias mais angulosas que os morrotes. Os morros possuem vertentes de declividades e altitudes relativamente altas, predominantemente, superiores a 29,99\% e entre 100 a $300 \mathrm{~m}$. Ocorrem com aumentos progressivos de declividades e altitudes em sentido noroeste, até a cota máxima de $398 \mathrm{~m}$, próxima aos limites do município de Pelotas com os de Canguçu. Esse padrão de relevo ocupa $309,23 \mathrm{~km}^{2}$. É o padrão de relevo predominante na área. 
Esses padrões de relevo resultam da dissecação das suítes granitoides, quando da sua exposição em superfície, ao longo do tempo geológico. De acordo com ROSS (1985), a compartimentação do relevo brasileiro atual, como o embasado pelo Escudo Sul-Rio-Grandense, tem fortes ligações genéticas com o soerguimento da Plataforma Sul Americana ao longo do Cenozoico (epirogênese pós-cretácea) e com os processos erosivos de caráter circundenudacionais que ocorrem desde então. Os processos erosivos foram de diferentes características, pois, ao longo de milhões de anos, processaram-se em diferentes ambientes climáticos (ROSS, 2013).

No território brasileiro, as estruturas e as formações litológicas são antigas, mas as formas do relevo são recentes. Estas foram produzidas pelos desgastes erosivos que sempre ocorrem e continuam ocorrendo, e com isso estão permanentemente sendo reafeiçoadas. Desse modo, as formas grandes e pequenas do relevo brasileiro têm como mecanismo genético, de um lado, as formações litológicas e os arranjos estruturais antigos, de outro, os processos mais recentes associados à movimentação das placas tectônicas e ao desgaste erosivo de climas anteriores e atuais. Grande parte das rochas e estruturas que sustentam as formas do relevo brasileiro são anteriores à atual configuração do continente sul-americano, que passou a ter o seu formato depois da orogênese andina e da abertura do oceano Atlântico, a partir do Mesozoico (ROSS, 2013, p. 10).

Os processos morfogenéticos do relevo estão condicionados à ação, direta e indireta, pretérita e atual, dos elementos e variáveis climáticas e aos aspectos estruturais e texturais das litologias do Batólito de Pelotas. As texturas inequigranulares com megacristais de menores estabilidades aos das matrizes; bandas mineralógicas irregulares e descontínuas; feições deformativas mineralógicas, decorrentes de esforços tectônicos; microfraturas; encurvamento de maclas; sobrecrescimento e recristalização mineralógica; clivagens irregulares; enclaves e zonas de deformação, sobretudo concentrados em bordas de intrusões; variações texturais na escala de afloramento; ocorrência de diques, de falhas tectônicas, de macrofraturas resultantes de alívio de pressão; a presença de enclaves, corpos estranhos imersos nas unidades plutônicas (FRAGOSO CESAR, Et. al., 1986; GOMES, 1990; PHILIPP, 1998; PHILIPP, R. P., NARDI, L. V. S., BITENCOURT, M. F., 2000), são quebras nas continuidades texturais e estruturais das litologias que favoreceram os processos de dissecação e morfoesculturação do relevo na área de estudo.

Nesse contexto, a ação hidrológica pluvial e fluvial, pela consolidação de redes de drenagens, merece destaque. A formação de caminhos preferenciais de escoamentos das águas, condicionados às linhas de fraqueza das litologias, entalharam as massas graníticas, originando vales. Em algumas superfícies, mais próximas aos divisores d'água, ainda se evidenciam feições geológicas, lineamentos, de controles estruturais, orientando a drenagem. Do entalhamento plúvio-fluvial remanescem as mais antigas superfícies do modelado da área, representadas pelos topos das colinas, morrotes e morros (Figura 4).

Esses relevos apresentam vertentes de geometrias retilíneas, convexas e côncavas que, em alguns casos, entre os topos e as baixas encostas se interdigitam. Nestas vertentes, recapeando as unidades litológicas, são observados eluviões, diferentes mantos de alteração pedogenética, especialmente, Neossolos Regolíticos 
e Argissolos Bruno-Acinzentados e Vermelho-Amarelos (CUNHA e SILVEIRA, 1996).

Figura 4: Formas de relevo da área de estudo.

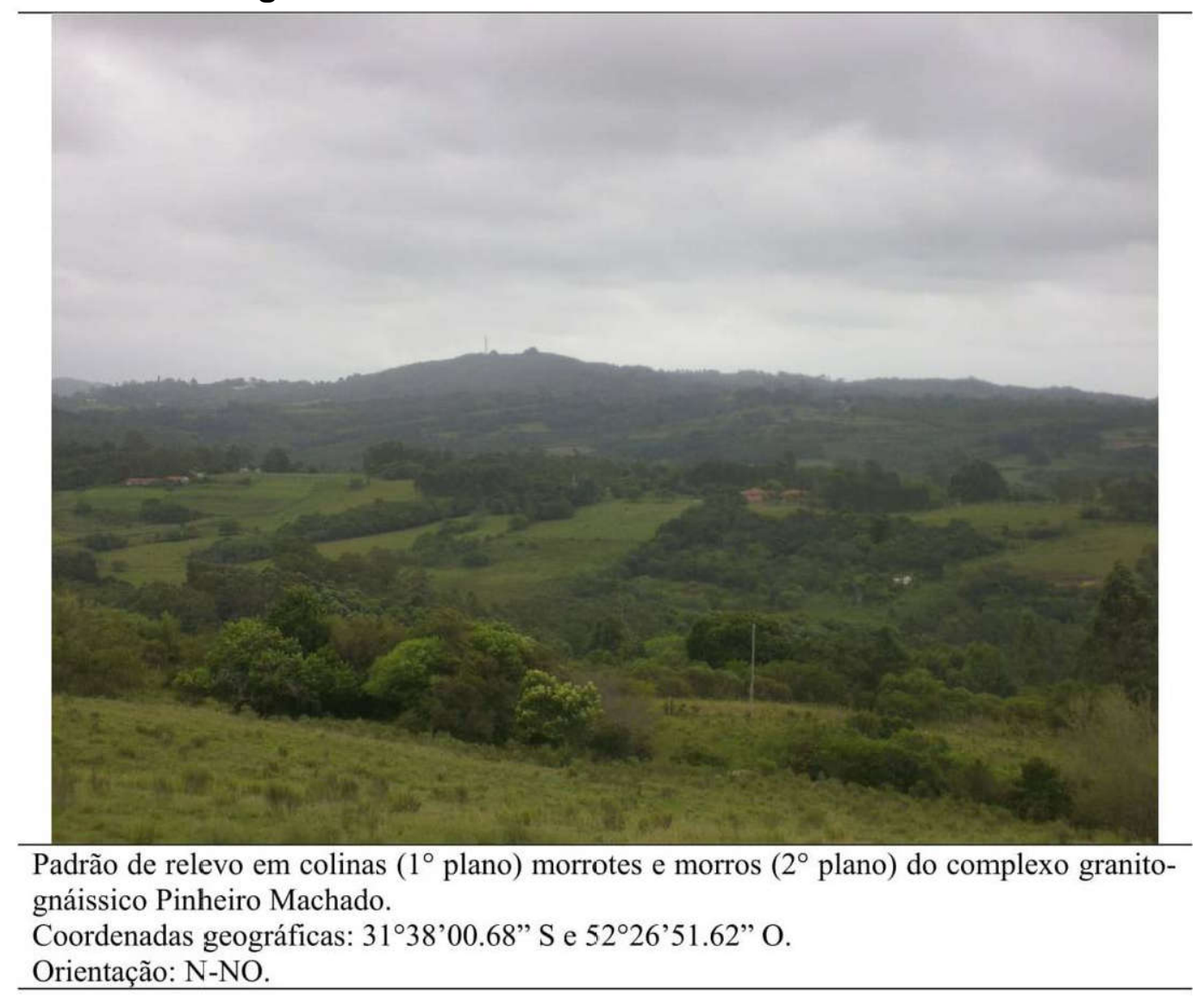

Fonte: Os autores.

Além dos eluviões, de naturezas pedogenéticas, também ocorre na constituição de colinas a sudeste na área de estudo, na transição com a Planície Costeira do RS, um pacote de sedimentos clásticos terrígenos, acumulados a partir de um sistema de leques aluviais. No passado geológico, as formas de relevo da área do Escudo, de modo geral, estruturavam-se por vertentes de declividades mais acentuadas e vales mais encaixados e profundos. Durante episódios de enxurradas intensas, por ocasião de torrentes, materiais detríticos foram mobilizados, formando leques aluviais ou cones de dejeção, apresentados em Tomazelli e Villwock (2000) como leques alimentados pelo Escudo.

O Sistema Deposicional de Leques Aluviais (...) engloba o conjunto de fácies sedimentares resultantes de processos de transporte associado aos ambientes de encosta das terras altas. Elas incluem, na sua parte mais proximal, depósitos resultantes de processos dominantemente gravitacionais como a queda de blocos, o rastejamento e o fluxo de detritos (tálus e coluviões) (...) (VILLWOCK E TOMAZELLI, 1995, p. 20).

Durante o Mioceno superior, a evolução desse sistema de leques dava-se por meio da interdigitação das fácies com o mar. No Quaternário, com a colmatação iniciada no complexo Patos-Mirim, essas fácies passaram a estar submetidas ao regime hidrodinâmico lagunar (TOMAZELLI \& VILLWOCK, 2000). 
Como consequência do predomínio de rochas fontes graníticas e da curta duração e distância do transporte, as fácies deste sistema, na área de estudos, têm como característica a imaturidade textural e mineralógica, exibindo uma composição essencialmente arcoseana. As fácies englobam os produtos de remobilização gravitacional de mantos de alteração das rochas graníticas (TOMAZELLI e VILLWOCK, 2000).

Essas formações e depósitos sedimentares foram retrabalhados, direta e indiretamente, por recorrentes alterações nas características dos perfis longitudinais dos canais fluviais que drenam a área de estudo, a partir de mudanças em seus níveis de base, decorrentes de ciclos transgressivo-regressivos marinhos de mudanças climáticas, correlacionáveis aos períodos interglaciais e glaciais do Cenozóico, como apontados em Tomazelli e Villwock (2000).

Alterações nos níveis de base dos cursos fluviais, de impactos em seus perfis longitudinais, resultam alterações em seus processos erosivos, de transporte e deposição, nas suas competências e capacidades fluviais (CUNHA, 2007). Também, por relações entre níveis basais, alteram-se as dinâmicas hidrológicas de encostas (COELHO NETTO, 2007), intensificando-se ora os processos pedogenéticos e ora os processos morfogenéticos do relevo em colinas, morrotes e morros da área de estudo.

\section{EVIDÊNCIAS MORFODINÂMICAS}

Sobre as colinas, morrotes e morros observaram-se feições erosivas lineares e, especialmente, evidências de processos erosivos laminares. A principal causa desses processos está associada ao desnudamento dos solos para práticas agrícolas, mineradoras e abertura de estradas, sem o devido cuidado técnico de implantação ou manejo.

Cobrindo uma superfície de $210,16 \mathrm{~km}^{2}$ a classe de solos expostos representa $23,4 \%$ do total da área de estudos. Esta classe se trata, sobretudo, de áreas de lavouras temporárias em preparos agrícolas. Na Figura 7 A é possível de se observar área de solo exposto sobre segmento de topo de morro do Granito Arroio Moinho. Os topos amplamente planos e suavemente convexos, sem a necessidade de cortes e terraceamentos, favorecem a implantação das práticas agrícolas.

Sobre os solos desnudos, com o impacto das gotas das chuvas, decorrem quebras de agregados, salpicamento, selamento e compactação e, em detrimento às reduções das infiltrações, o desenvolvimento de escoamentos superficiais, potencialmente erosivos.

Contiguo as áreas de lavouras, onde se observam solos desnudos, chama atenção às formações de depósitos sedimentares de granulometrias variadas, predominantemente arenosas. Esses depósitos ocorrem, sobretudo, em segmentos de vertentes onde se verificam rupturas de declives que marcam a transição entre as diferentes formas de relevo. Em muitos desses casos não se observaram feições erosivas lineares na área, como sulcos ou ravinas, assim, esses depósitos foram caracterizados como resultantes de erosão laminar.

A ocorrência de seixos e matacões em segmentos de vertentes do relevo, onde se verificam coberturas herbáceas esparsas, mediante a formação de pequenos depósitos de granulometrias bastante variadas em posições de jusante, também são indicativos do desenvolvimento de processos erosivos laminares. As coberturas herbáceas ocupam uma área de $488,72 \mathrm{~km}^{2}$, cobrindo $54,4 \%$ da área de 
estudo, todavia, em função das variações de disponibilidade hídricas sazonais, tornam-se esparsas em períodos de estiagem.

Figura 7: Formas de processos erosivos em morros e morrotes.

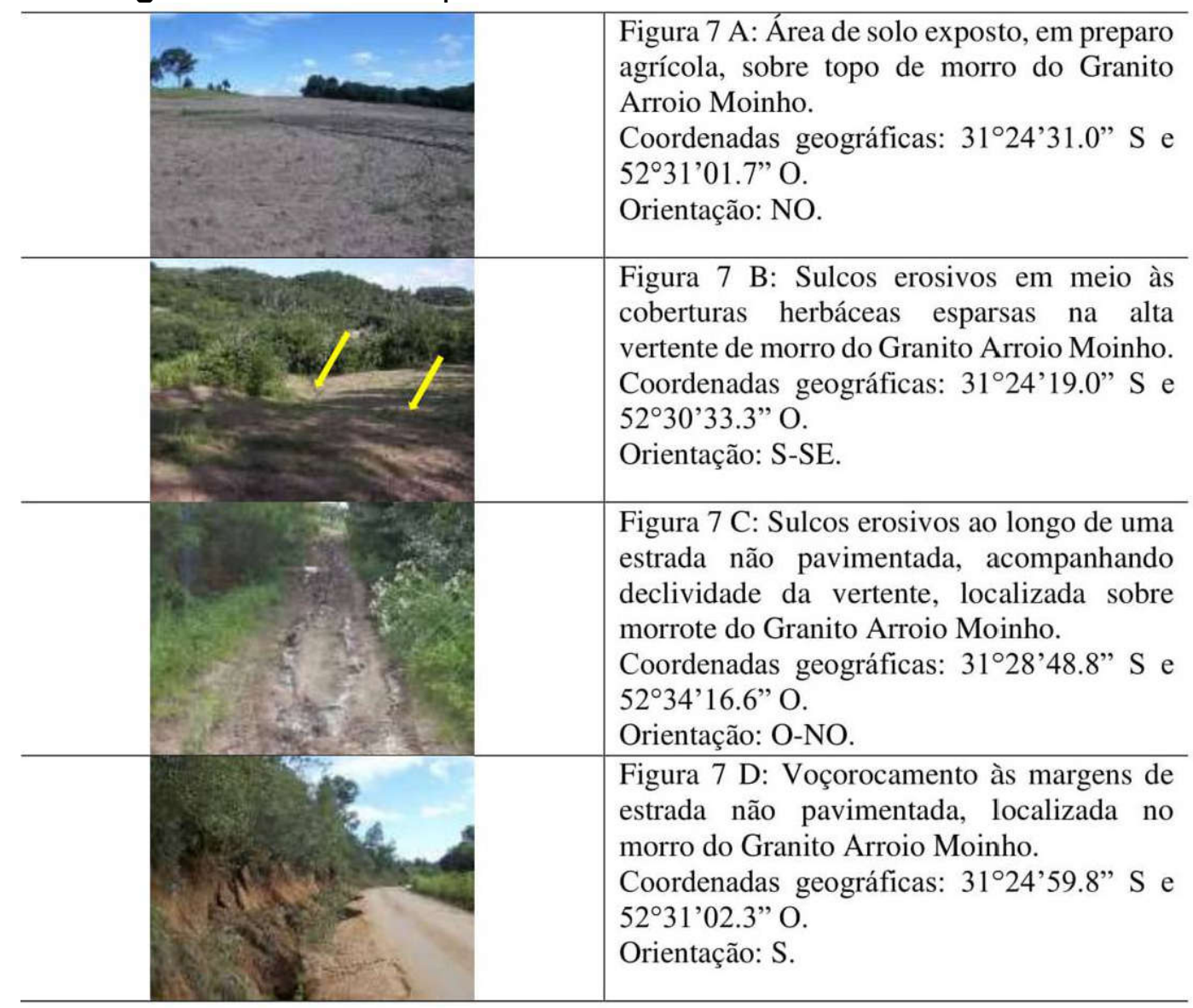

Fonte: Os autores.

Os seixos e matacões se destacam em altas vertentes, de declividades relativamente acentuadas, assim como, em topos convexos de morros e morrotes estruturados pelo granito Arroio Moinho. Sobre esses terrenos, além dos afloramentos rochosos, são verificados Neossolos, mantos de alteração pouco espessos, em muitos casos, pobres em matéria orgânica, de partículas fracamente coesas e de textura arenosa cascalhenta. A pouca profundidade do material alterado, suas características texturais e de abrupto contato lítico, indicam se tratar de solos de fácil saturação e de rápida promoção de escoamentos.

As feições erosivas lineares como sulcos e ravinas foram observadas, especialmente, nas médias e baixas vertentes de morros, morrotes e colinas, sobre Neossolos e Argissolos. As formas de processos lineares resultam do escoamento superficial concentrado, orientado pelas declividades e geometrias, especialmente, convexo-côncavas das encostas. Desenvolvem-se a partir de terrenos de solos desnudos, em áreas de preparos agrícolas não terraceados e ou onde ocorrem coberturas herbáceas esparsas (Figura 7 B).

Também foram observadas feições erosivas lineares, como sulcos, ravinas e voçorocas, em estradas não pavimentadas. Os sulcos e ravinas ocorrem comumente sobre as estradas quando estas acompanham os declives das vertentes (Figura 7 C). As voçorocas foram observadas em posições marginais às vias, paralelas aos taludes de cortes (Figura 7 D). Estes funcionam como barreiras à dissipação do 
escoamento superficial, canalizando-o e, no processo erosivo, formando incisões de maiores profundidades, até o alcance do escoamento basal. Na base das voçorocas se observam cones de dejecção, retrabalhados em sentido das jusantes quando de ocorrências pluviométricas mais intensas.

\section{CABECEIRAS DE DRENAGEM, HOLLOWS E PLANÍCIES}

As cabeceiras de drenagem e hollows correspondem às vertentes côncavas, formas de anfiteatros em colinas, morrotes e morros, onde se observam afloramentos d'água perenes e intermitentes, áreas de nascentes fluviais. Apresentam declividades e altitudes bastante variadas e ocorrem, majoritariamente, próximos aos segmentos de topos do relevo. Ocupam 59,68 km².

As planícies correspondem às superfícies relativamente planas ou de baixas declividades, onde se observam notórios processos de agradação sedimentar. Distribuem-se por toda área de estudo, em conformidade à rede de drenagem fluvial. Por suas características morfológicas, mas também morfogenéticas, as planícies foram seccionadas enquanto alveolares e fluviais.

As planícies alveolares apresentam superfícies de declividades inferiores a $5 \%$, mas ocorrem em altitudes e como fundos de vales de larguras bastante variadas, ora mais largas, ora mais estreitas, suas aberturas notoriamente são interrompidas pela sucessão de materiais de resistências diferenciadas a erosão. Ocupam 225,96 km².

O padrão de relevo em planícies fluviais apresenta superfícies de declividades e altitudes, respectivamente, inferiores a $5 \%$ e $40 \mathrm{~m}$. Compreendem fundos de vales com progressivos alargamentos no sentido das jusantes. Ocupam 63,72 km².

As cabeceiras de drenagens, com formação de hollows, atualmente se desenvolvem a partir de processos plúvio-fluviais em vertentes de geometrias côncavas (Figura 5 A).

Figuras 5: Formas de relevo da área de estudo.

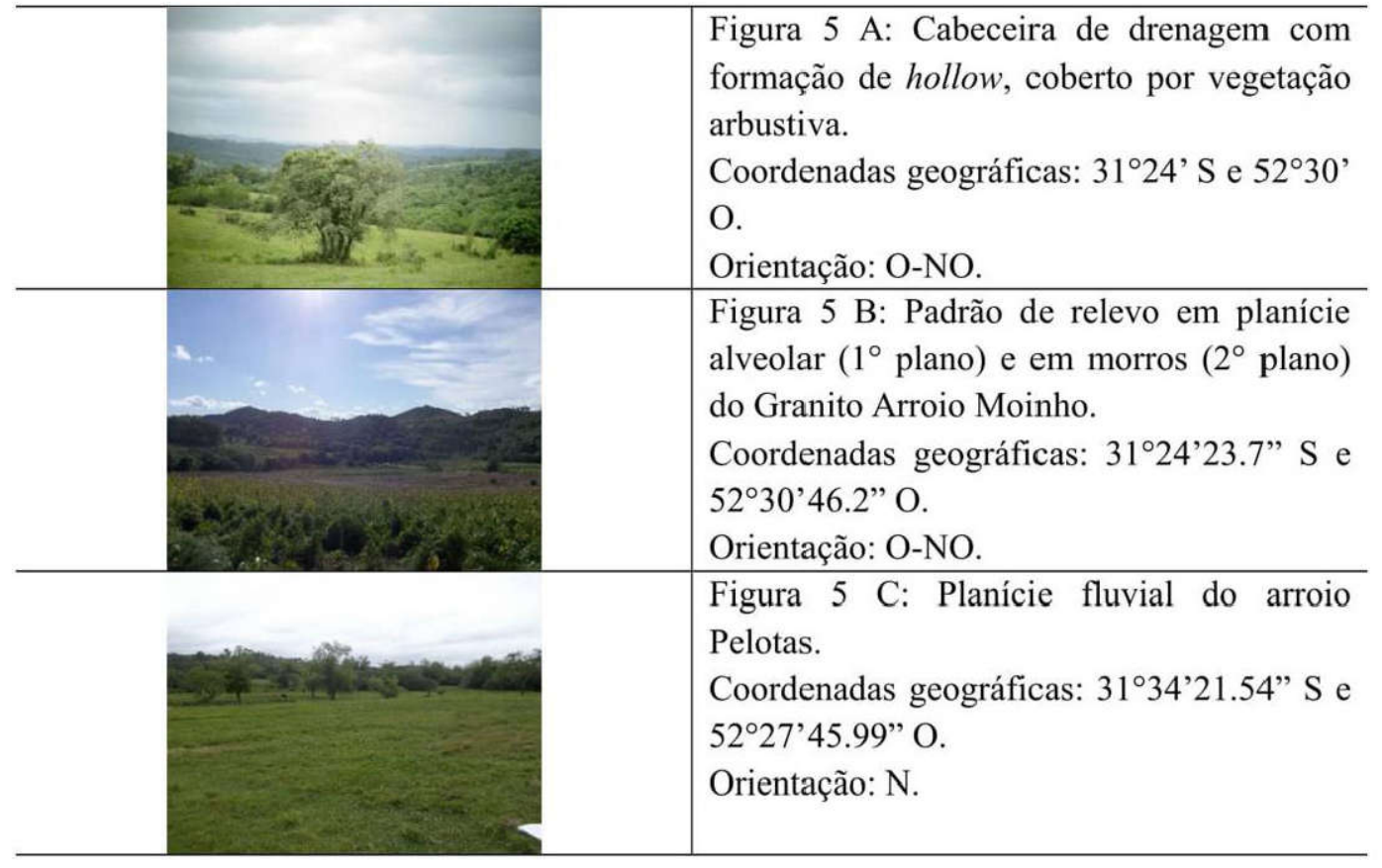

Fonte: Os autores. 
Observações de campo e análises em gabinete, de ênfases morfológicas e morfogenéticas, permitem hipóteses sobre a evolução dessas formas de relevo. De modo geral, estão articuladas a lineamentos geológicos e, com o retrabalhamento de materiais pedogenéticos, evoluem acompanhando as fases de encaixamento da rede de drenagem, conforme modificações nos seus níveis de base, locais/ estruturais ou regionais, pelas transgressões e regressões marinhas desde 0 Pleistoceno.

Os hollows correspondem aos segmentos de vertentes concentradores de fluxos hídricos. Essas unidades do relevo indicam as orientações e as intensidades dos processos morfogenéticas operantes na dissecação das colinas, dos morrotes e morros da área. Quando próximos aos divisores d'água, por vezes, seccionam topos, possibilitando a compartimentação de distintas formas e ou feições geomorfológicas.

Os hollows são também definidos, para além de seus aspectos morfológicos e morfogenéticos, com base na hierarquia fluvial. No contexto da área de estudo, contemplam setores de nascentes (olhos d'água) e de canais fluviais de primeira ordem (STRAHLER, 1952 apud CUNHA, 2007), dos quais, muitos intermitentes.

Os hollows ocorrem à jusante de vertentes côncavas dos padrões de formas de relevo em colinas, morrotes e morros e à montante das planícies. A relação dos hollows com as vertentes côncavas têm natureza genética, pois, resultam da erosão regressiva dessas vertentes, com seus aprofundamentos, alargamentos e entulhamentos.

Por sua vez, as planícies resultam das progressões dos hollows, a partir de reestruturações hierárquicas fluviais da rede de drenagem. Definidas enquanto alveolares e fluviais, os limites entre essas três formas de relevo são de difícil precisão, pois, alternam-se sazonalmente, por meio das variações pluviométricas e intrincadas relações de trocas entre matéria e energia.

As planícies alveolares constituem fundos de vales, depressões entulhadas de sedimentos, de extensões e larguras bastante variadas (Figura 5 B). São superfícies seccionadas por estrangulamentos flúvio-geomorfológicos, resultantes de lineamentos geológicos e da resistência diferencial das estruturas graníticas, modeladas por processos plúvio-fluviais.

As planícies alveolares compreendem superfícies que estabelecem dinâmicas fluviais entre hollows e planícies fluviais. São drenadas por canais fluviais de segunda ou maior ordem (STRAHLER, 1952 apud CUNHA, 2007) e muitos desses canais são intermitentes. Sobre essas planícies se observam depósitos de sedimentos aluviais de texturas bastante variadas, indicadores de fluxos irregulares.

Por fim, nas planícies fluviais os processos geomorfológicos agradacionais se destacam frente aos processos denudacionais. Compreendem superfícies de depósitos sedimentares provindos das vertentes adjacentes (Figura $5 \mathrm{C}$ ). Os depósitos identificados são de sedimentos menos grosseiros e de maior uniformidade textural do que os observados nas planícies alveolares. As ocorrências de depósitos com essas características são indicativos de fluxos mais regulares de escoamento.

Nas planícies fluviais, em áreas marginais aos cursos d'água, são observados solos hidromórficos, mal drenados. Nessas áreas, o lençol freático é menos profundo e o escoamento subsuperficial parece ter importante contribuição na regulação das vazões fluviais. Muitas dessas superfícies também se caracterizam como planícies 
de inundações, pois, pouco elevadas acima do nível médio das águas fluviais, são sazonalmente ocupadas pelas águas de escoamento.

Analogias morfológicas e morfogenéticas possibilitam o mapeamento de sete planícies fluviais, são elas, as planícies dos arroios Fragata, Pelotas, Contagem, Valentim, Corrientes, do Padre e Grande.

\section{EVIDÊNCIAS MORFODINÂMICAS}

As cabeceiras de drenagens e hollows, por suas geometrias côncavas, são áreas concentradoras de fluxos hídricos, superficiais e subsuperficiais, onde se observam mantos de alteração mais espessos e nascentes fluviais. $\mathrm{Na}$ área de estudo foram mapeadas 1587 cabeceiras de drenagens com formação de hollows.

Esses segmentos de vertentes estabelecem uma conexão muito dinâmica das águas de escoamentos entre os morros, morrotes e colinas com as planícies, sobretudo alveolares. Ao abrigarem nascentes fluviais, esses segmentos de vertente são legalmente reconhecidos como Áreas de Preservação Permanente (APPs), todavia, pela ausência da cobertura florestal nativa, identificam-se diversos conflitos de usos.

Sobre as áreas de planícies, alveolares e fluviais, observam-se formações de áreas úmidas, das mais variadas dimensões, regionalmente conhecidas como banhados (Figura $8 \mathrm{~A}$ ). A área de influência dos banhados fica mais evidente quando da ocorrência de maiores índices pluviométricos e ascensão do lençol freático.

As áreas úmidas possuem importância ecológica, pela biodiversidade que agregam, e hidrológica, pois funcionam como reguladoras da vazão fluvial. Em momentos de maiores índices pluviométricos as áreas úmidas retêm as águas das chuvas, mitigando inundações fluviais, e, nos períodos de estiagem, contribuem para manutenção da perenidade dos cursos d'água adjacentes.

Todavia, dadas suas características geomorfológicas e pedológicas, superfícies planas, baixas declividades e ocorrência de um manto de alteração mais desenvolvido, tornam-se, em alguns casos posteriores aterramentos, áreas para práticas agrícolas. Os aterros, de modo geral, compactam os solos e reduzem os processos de infiltração e percolação subsuperficial, potencializando escoamentos superficiais.

Nas áreas de planícies, em segmentos marginais aos cursos d'água, também chama atenção os solapamentos de taludes fluviais e as formações de bancos de sedimentos, majoritariamente arenosos.

Os solapamentos de taludes fluviais, de modo geral, estão associados à retirada da vegetação ciliar (Figura 8 B). O sistema radicular da vegetação, pela fixação do manto de alteração, desempenha importante papel na contenção das quedas dos taludes. Tais solapamentos são comumente observados nos altos cursos fluviais, em seções mais próximas às cabeceiras de drenagens e aos divisores d'água, setores que respondem rapidamente as ocorrências pluviométricas, com alterações abruptas de suas vazões.

Os bancos de sedimentos são observados nos leitos e marginais aos cursos d'água. Nos leitos fluviais, em alguns casos, a formação desses depósitos está associada aos próprios solapamentos fluviais, os quais, pela progressiva queda de taludes, ampliam as distâncias entre as margens e reduzem as profundidades das calhas fluviais, assoreando-as (Figura $8 \mathrm{C}$ ).

Os assoreamentos fluviais, quando da ocorrência de índices pluviométricos mais expressivos, chuvas intensas e ou acumuladas, condicionam o 
transbordamento das águas de escoamento das calhas fluviais, inundando as áreas de planícies.

Figura 8: Morfodinâmicas em planícies.

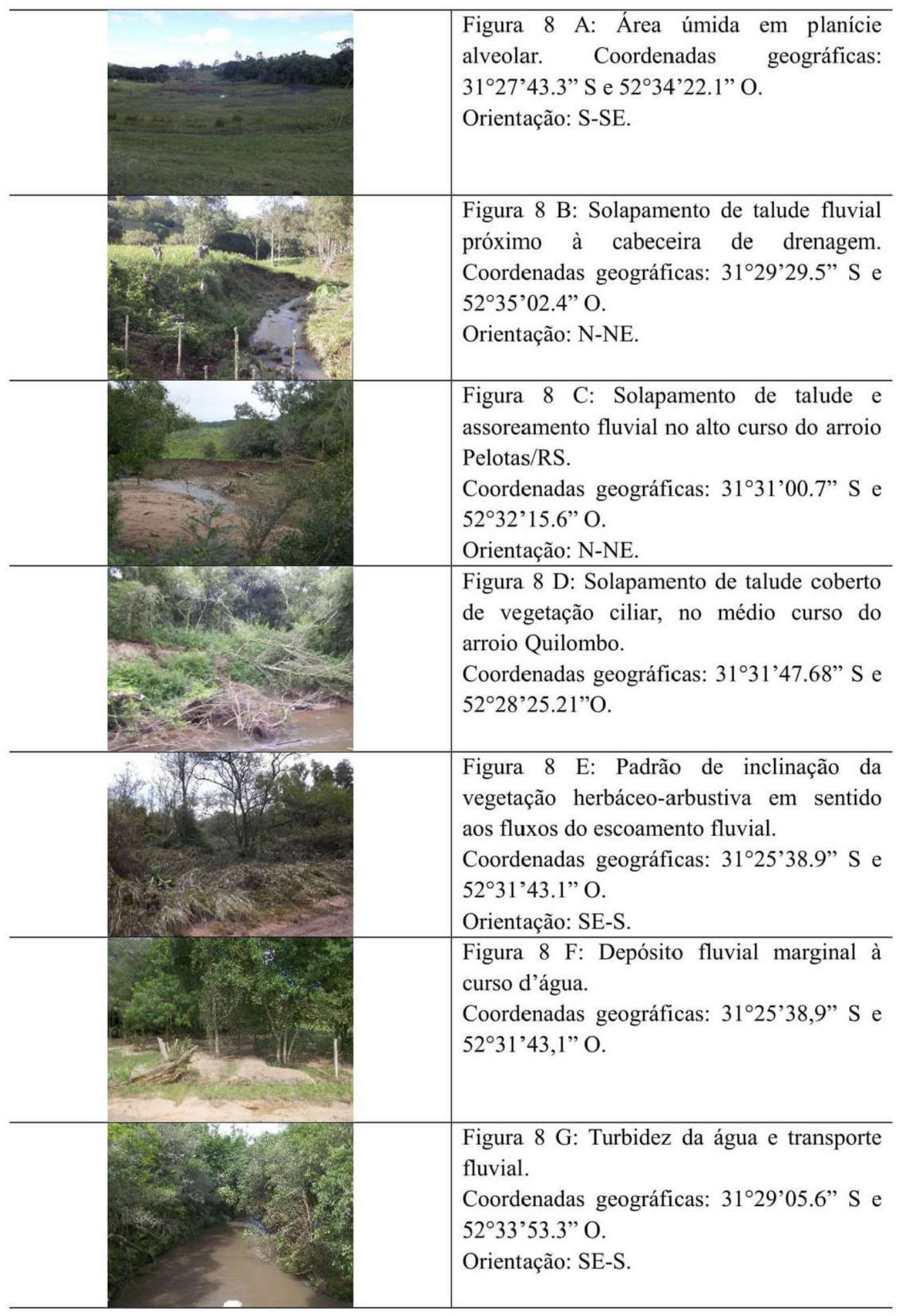

Fonte: Os autores.

Dados de normal climatológica de precipitação, do período de 1971 a 2000, obtidos da Estação Agroclimatológica de Capão do Leão, referência para região, 
indicam ocorrências de índices de médias superiores a $140 \mathrm{~mm}$ para os meses de fevereiro e julho. Nos demais meses, a exceção de março, as médias pluviométricas são iguais ou superiores a $100 \mathrm{~mm}$. (EMBRAPA/ UFPEL/ INMET, 2015).

Conforme Rutz (2015) são periodicamente observadas na área chuvas torrenciais e enxurradas, por vezes, associadas a eventos extremos, em que se registram valores bem acima das normais pluviométricas mensais. Caso do evento ocorrido entre os dias 28 e 29 de janeiro de 2009, com índices superiores a $600 \mathrm{~mm}$ em 24h.

Foram observados em campo, enquanto indícios das inundações e do seu alcance, os solapamentos de taludes cobertos de vegetação ciliar, o padrão de inclinação da vegetação herbáceo-arbustiva em sentido aos fluxos fluviais e a formação de bancos de depósitos arenosos marginais aos cursos d'água (Figura 8 $D, E, F)$.

Esses depósitos sedimentares são retrabalhados a cada nova ocorrência pluviométrica, conforme impactos nas competências fluviais. $O$ transporte sedimentar é verificado pelas colorações brunadas das águas (Figura $8 \mathrm{G}$ ). Tais colorações indicam o transporte dos sedimentos que produtos dos solapamentos dos taludes de margens dos arroios e da erosão acelerada de material pedogenético das vertentes adjacentes.

\section{MAPEAMENTO GEOMORFOLÓGICO}

O mapa geomorfológico da área de influência do Escudo Sul-Rio-Grandense no município de Pelotas/RS, enquanto síntese deste trabalho, espacializa e sistematiza dados morfológicos (morfográficos e morfométricos), morfogenéticos e morfodinâmicos do relevo da área de estudo, considerando-se associações litoestatigráficas e pedológicas (Figura 9 A/ B). 
Figura 9 A: Mapa geomorfológico da área de influência do Escudo Sul-RioGrandense no município de Pelotas/RS.

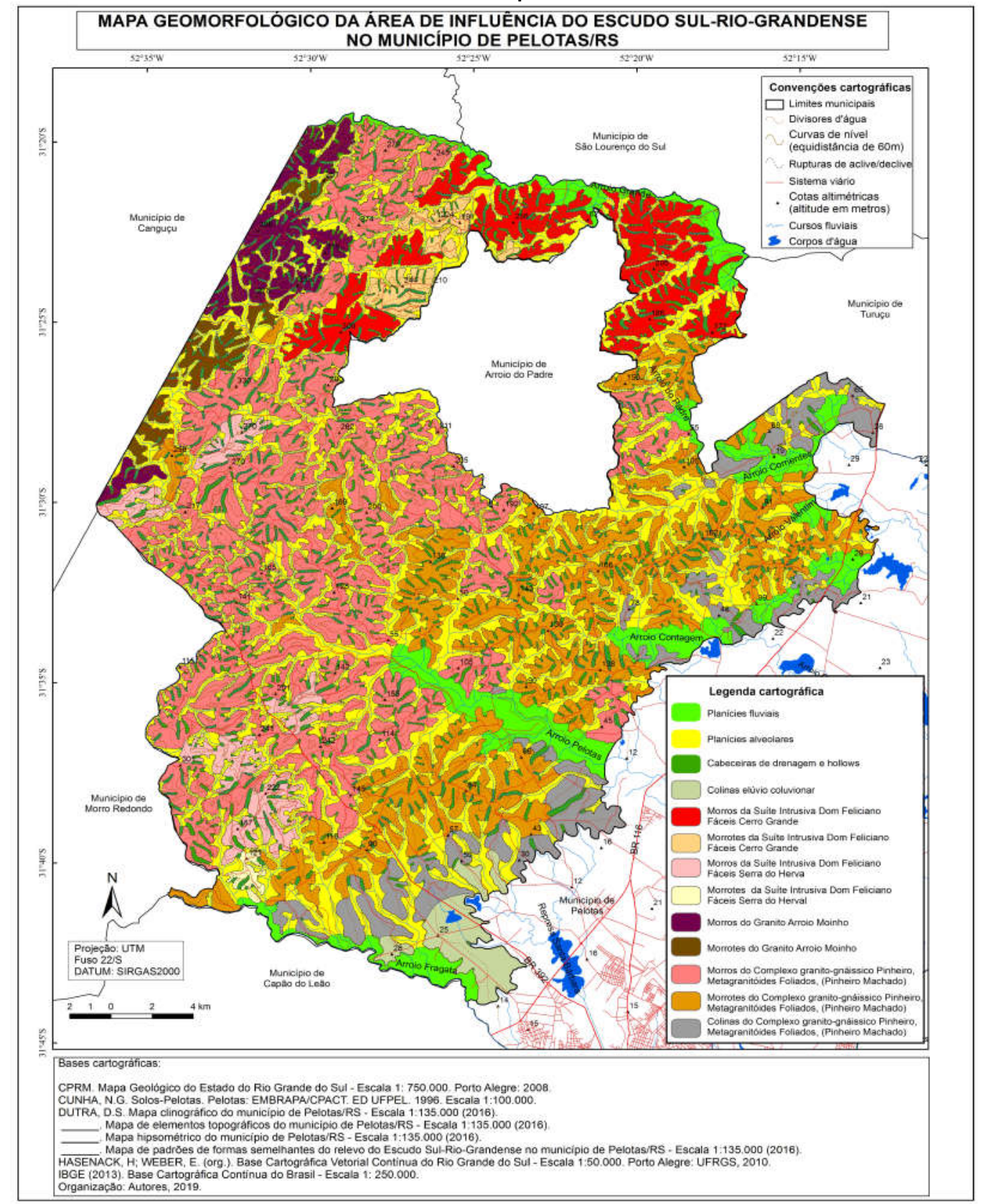

Fonte: Os autores. 
Figura 9 B: Legenda do mapa geomorfológico da área de influência do Escudo SulRio-Grandense no município de Pelotas/RS.

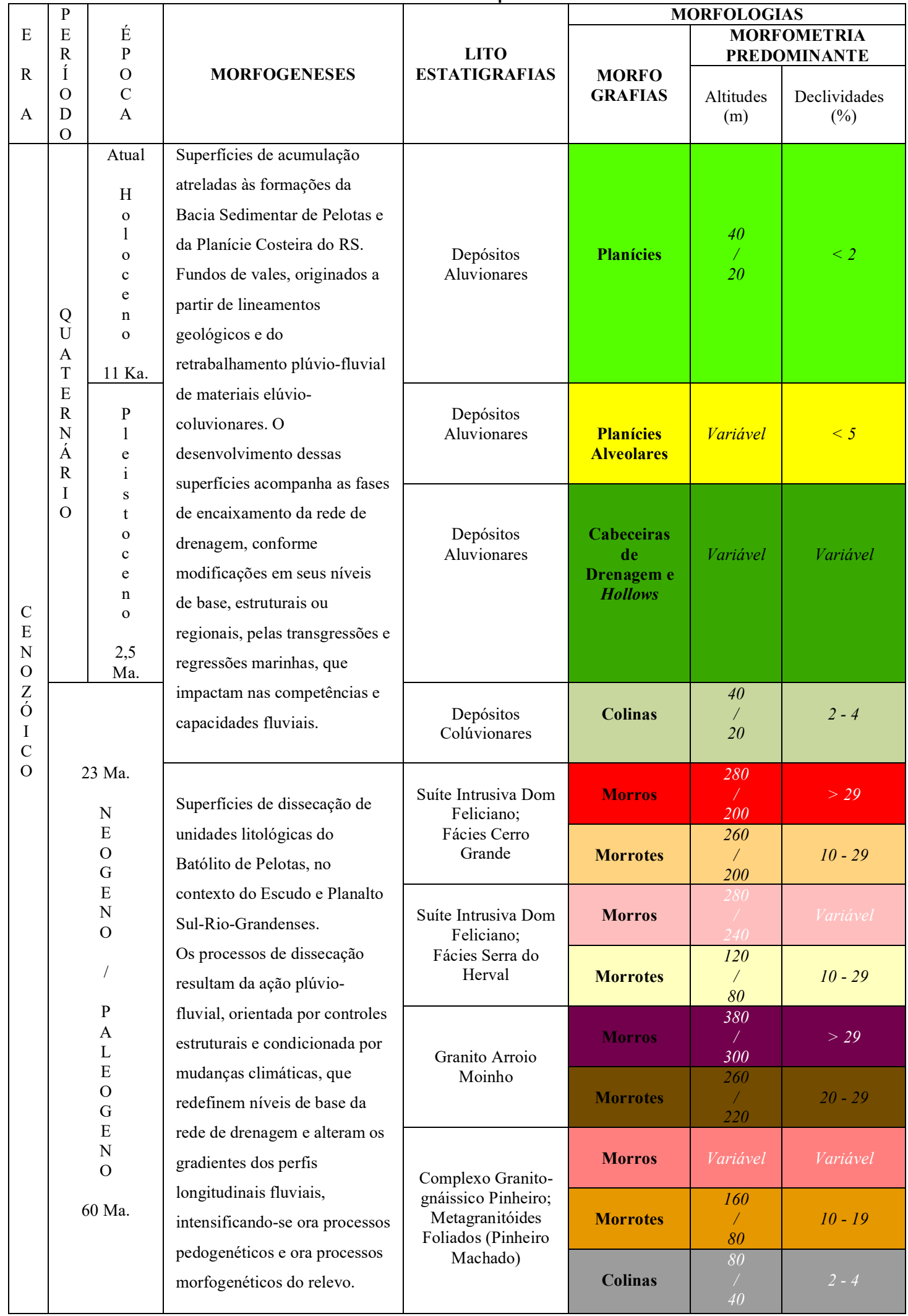

\section{MORFOLOGIAS}

MORFODINÂMICAS 


\begin{tabular}{|c|c|c|}
\hline $\begin{array}{c}\text { Planícies } \\
/ \\
\text { Planícies Alveolares } \\
/ \\
\text { Cabeceiras de Drenagem } \\
\text { e Hollows }\end{array}$ & $\begin{array}{l}> \\
>\end{array}$ & $\begin{array}{l}\text { Formação de ARGISSOLOS, NEOSSOLOS flúvicos e PLANOSSOLOS (mal } \\
\text { drenados); } \\
\text { Formação de áreas úmidas, de dimensões variadas, reguladoras de fluxos hídricos (em } \\
\text { períodos de elevados índices pluviométricos, essas superfícies acumulam águas } \\
\text { pluviais e mitigam inundações fluviais e em períodos de estiagem contribuem para } \\
\text { manutenção da perenidade dos cursos d'águas às jusantes); } \\
\text { Formação de aterros para práticas agrícolas e compactação dos solos (possível redução } \\
\text { dos processos de infiltração e percolação subsuperficial e potencialização de } \\
\text { escoamentos superficiais); } \\
\text { Solapamentos de taludes fluviais; } \\
\text { Assoreamentos fluviais; } \\
\text { Inundações. }\end{array}$ \\
\hline $\begin{array}{c}\text { Morros } \\
\text { / } \\
\text { Morrotes } \\
/ /\end{array}$ & & $\begin{array}{l}\text { Formação de Afloramentos Rochosos, NEOSSOLOS Regolíticos e ARGISSOLOS } \\
\text { (mantos de alteração de rápida saturação, pela ocorrência de solos rasos e ou de } \\
\text { mudança textural - Bt - abrupta); } \\
\text { Formação de feições erosivas lineares e evidências de processos erosivos laminares, } \\
\text { associados ao desnudamento dos solos para práticas agrícolas, mineradoras e aberturas } \\
\text { de estradas, sem o devido cuidado técnico de implementação ou manejo; } \\
\text { Ocorrências de seixos e matacões em segmentos de vertentes onde se observam } \\
\text { coberturas herbáceas esparsas, mediante formação de depósitos de granulometrias } \\
\text { variadas em posições de jusante, indicativos do desenvolvimento de processos erosivos } \\
\text { laminares; } \\
\text { Voçorocamentos marginais às estradas não pavimentadas, paralelos taludes de cortes, } \\
\text { sem adequados sistemas de drenagem. }\end{array}$ \\
\hline
\end{tabular}

Fonte: Os autores.

\section{CONSIDERAÇÕES FINAIS}

Os materiais e métodos empregados nesta pesquisa foram eficientes no mapeamento geomorfológico da área de estudo, possibilitando a organização de dados morfológicos, morfogenéticos e morfodinâmicos do relevo.

O estudo da evolução do modelado da área de influência do Escudo contribui para o entendimento hidrogeomorfológico de áreas circunvizinhas, como áreas de influência da Planície Costeira do RS no município. A intensificação de fluxos superficiais sobre vertentes do relevo do Escudo resulta em alterações mais abruptas de vazões fluviais, promovendo solapamentos de margens, assoreamentos e inundações. As inundações impactam as planícies flúvio-lacustres da Planície Costeira do RS e recorrentemente deixam submersas áreas do perímetro urbano de Pelotas.

A mitigação dos efeitos dos processos morfodinâmicos do relevo requer a preservação da vegetação em áreas de topos de morros e morrotes, de vertentes de declividades acentuadas, marginais aos cursos fluviais, áreas úmidas e nascentes.

Nesse sentido, esta pesquisa serve de base para construção de novos produtos, como mapeamentos de APPs. A partir da individualização das formas de relevo e o mapeamento dos divisores d'água, o trabalho traz informações úteis na determinação de APPs de topos de morros e morrotes. Por sua vez, a delimitação de cabeceiras de drenagens e hollows orienta uma melhor definição das APPs de nascentes fluviais. Com o mapeamento de 1587 cabeceiras de drenagens com formação de hollows, cabe-se destacar o potencial da área de estudo em ocorrências de nascentes fluviais.

Ademais, há de se pensar em medidas de recuperação das áreas degradadas, como as margens fluviais em processos de solapamento. As ações devem ir do replantio de espécies nativas à promoção de políticas de subsídios e orientações técnicas para o desenvolvimento de práticas agrícolas menos impactantes, de conservação das matas ciliares e de educação ambiental.

$\mathrm{Na}$ perspectiva da educação ambiental, os resultados deste estudo servem como instrumento para a produção de materiais paradidáticos aos níveis de ensino 
básico e superior, contribuindo para o desenvolvimento de projetos de extensão de conscientização ambiental em comunidades escolares, especialmente da zona rural.

Por fim, destaca-se que o mapeamento geomorfológico da área de influência do Escudo, combinado ao da área de influência da Planície Costeira do RS, possibilitará o mapeamento geomorfológico do município de Pelotas e se apresenta como uma referência geomorfológica para municípios limítrofes ou bacias hidrográficas contíguas a área de estudo, em virtude da abrangência regional do Escudo Sul Rio-Grandense.

\section{REFERÊNCIAS}

ARGENTO, M.S.F. Mapeamento geomorfológico. In: GUERRA, A.J.T; CUNHA. S.B (Orgs). Geomorfologia: uma atualização de bases e conceitos. Rio de Janeiro: Bertrand Brasil, 2009. P. 365 - 92.

COELHO NETTO, A. L. Hidrologia de encosta na interface com a Geomorfologia. In: GUERRA, A. J. T.; CUNHA, S. B. (Orgs.). Geomorfologia: uma atualização de bases e conceitos. $7^{\circ}$ ed. Rio de Janeiro: Bertrand Brasil, 2007. P. $93-148$.

CUNHA, N. G.; SILVEIRA, J. C. Estudo dos solos do município de Pelotas. 1:100.000 Pelotas: EMBRAPA/CPACT, Ed. UFPEL, 1996. 50p.

CUNHA, S. B. Geomorfologia Fluvial. In: GUERRA, A. J. T.; CUNHA, S. B. (Orgs.). Geomorfologia: uma atualização de bases e conceitos. $7^{\circ}$ ed. Rio de Janeiro: Bertrand Brasil, 2007. P. 211-52.

DEMEK, J., EMBLETON, C., GELLERT, J. F. \& VERSTAPPEN, H. T. (Eds.). Manual of Detailed Geomorphological Mapping. International Geographical Union Commission on Geomorphological Survay and Mapping. Academia, Prague. 1972. $320 \mathrm{p}$.

EMBRAPA SOLOS. Sistema Brasileiro de Classificação de Solos. $3^{\circ}$ ed. Brasília, DF: Embrapa, 2013, p.296-97.

EMBRAPA/UFPEL/INMET. Disponível em: < http://wp.ufpel.edu.br/agrometeorologia/informacoes/clima-de-pelotas >. Acesso em: 30 de jul. 2015.

FAVILLA, C. A.; CALDASSO, A. L. S.; RODRIGUES, T. L. N.; WILDNER, W.; BACHI, F. A.; VILLWOCK, J. A.; TOMAZELLI, L. J.; DEHNHARDT, B. A. Mapas Geológicos da Região Costeira do Rio Grande do Sul - Escala 1:250.000. Porto Alegre: CPRM/UFRGS, 2000. (Folha SH.22-Y-D - Pelotas).

FLORENZANO, T. G. (Org.). Geomorfologia: conceitos e tecnologias atuais. São Paulo: Oficina de Textos, 2008. 318p.

FORÇA AÉREA BRASILEIRA (FAB); AGÊNCIA DA LAGOA MIRIM (ALM). Levantamento Aerofotogramétrico de 1953. Pelotas, 1953. Escala 1:40.000.

FRAGOSO CESAR, A. R. S.; FIGUEIREDO, M. C. H.; SOLIANI Jr., E. \& FACCINI, U. F. O Batólito de Pelotas (Proterozóico Superiorl Eo-Paleozóico) no Escudo do Rio Grande do Sul. In: CONGRESSO BRASILEIRO DE GEOLOGIA, 34, 1986, Goiânia. Anais..., Goiânia, SBG, v3, p. 1322-43. 
GOMES, M. E. B. Petrologia do Granito Arroio Moinho, Canguçu (RS):

geoquímica e deformação. Dissertação de Mestrado. Curso de Pós-Graduação em Geociências, Universidade Federal do Rio Grande do Sul, 1990. 199p.

GUERRA, A.T. \& GUERRA, A. J. T. Novo Dicionário Geológico-Geomorfológico. Rio de Janeiro: Bertrand Brasil, 1997, 652 p.

HASENACK, H.; WEBER, E. (Orgs.) Base cartográfica vetorial contínua do Rio Grande do Sul - escala 1:50.000. Porto Alegre: UFRGS - IB - Centro de Ecologia. 2010. 1 DVD-ROM (Série Geoprocessamento, 3).

IBGE, Instituto Brasileiro de Geografia e Estatística. Manual Técnico de Geomorfologia. $2^{\circ}$ ed. Rio de Janeiro: IBGE, 2009. 178p.

Manual Técnico de Uso da Terra. $3^{\circ}$ ed. Rio de Janeiro: IBGE, Departamento de Recursos naturais e Estudos Ambientais, Primeira Divisão de Geociências do Nordeste, 2013. 171p.

Base Cartográfica Contínua do Brasil na escala de 1:250.000. 2013. Disponível em: < https://mapas.ibge.gov.br/bases-e-referenciais/basescartograficas/malhas-digitais.htm >. Acesso em: 10 dez. 2015.

INPE, Instituto Nacional de Pesquisas Espaciais. Imagens do satélite Landsat, instrumento TM5. Brasil, Pelotas. Órbita/Ponto 222/82. Obtidas em: 23 out. 2011. Resolução de 30m. Disponível em: < http://www.dgi.inpe.br/CDSR/ >. Acesso em: 05 de set. 2015.

KLIMASZEWSKI, M. Detailed geomorphological maps. ITC Journal. P. 265-271, 1982.

MARTH, J. D.; KOESTER, E.; ARNDT, A. L. Mapa geológico-geomorfológico do município de Pelotas, RS. In: XVII Congresso de Iniciação Científica (CIC)/X Encontro de Pós-Graduação (ENPOS), 2008, Pelotas. Anais de Ciências Exatas e da Terra. Pelotas: UFPel. 2008. P. 1-5.

MENEGAT, R.; FERNANDES, L. A.D.; KOESTER, E. \& SCHERER, C. M. S. Porto Alegre antes do homem: evolução geológica. In: MENEGAT, R. (org.). Atlas Ambiental de Porto Alegre. Porto Alegre: UFRGS, 1998. P. 11 - 14.

PHILIPP, R. P. A Evolução Geológica e Tectônica do Batólito de Pelotas no Rio Grande do Sul. São Paulo. TESE. Doutorado em Geociências, Instituto de Geociências, Universidade de São Paulo, 1998. 255p.

PHILIPP, R. P., NARDI, L. V. S. \& BITENCOURT, M. F. O Batólito de Pelotas no Rio Grande do Sul. In.: HOLZ, M. \& DE ROS, L. F. (Editores). Geologia do Rio Grande do Sul. Edição CIGO/ UFRGS. 2000. P. 133-60.

REHBEIN, M. O. Mapeamento geomorfológico aplicado na análise de impactos ambientais urbanos: contribuições ao (re) conhecimento de morfologias, morfocronogêneses e morfodinâmicas do relevo da bacia hidrográfica do arroio Feijó - RS. TESE. Doutorado em Geografia Física. Departamento de Geografia da Faculdade de Filosofia, Letras e Ciências Humanas, Universidade de São Paulo, São Paulo, 2011. 339p.

RODRIGUES, C. Geomorfologia aplicada: Avaliação de experiências e de instrumentos de planejamento físico-territorial e ambiental brasileiros. TESE. Doutorado em Geografia Física. Departamento de Geografia da Faculdade de 
Filosofia, Letras e Ciências Humanas da Universidade de São Paulo, São Paulo, 1997, $280 \mathrm{p}$.

ROSS, J. L. S. Análise empírica da fragilidade dos ambientes naturais e antropizados. Revista do Departamento de Geografia. Vol. 08, FFLCH/ USP, São Paulo, 1994. P. 63-74.

Relevo brasileiro: uma nova proposta de classificação. Revista do Departamento de Geografia. Vol. 04, FFLCH/ USP, São Paulo, 1985. P. 25-39.

. O Registro Cartográfico dos Fatos Geomorfológicos e a Questão da Taxonomia do Relevo. Revista do Departamento de Geografia, n. 6, FFLCH/USP, São Paulo, 1992. P. 17-29.

O relevo brasileiro nas macroestruturas antigas. Revista Continentes (UFRRJ), ano 2, n.2, 2013. P. 08-27.

RUTZ, E. C. Análise histórica das enxurradas no município de Pelotas e as conseqüências da enxurrada de 2009 na Bacia Hidrográfica do Arroio Quilombo, Pelotas/RS. DISSERTAÇÃO. Mestrado em Geografia - Programa de Pós-Graduação em Geografia, Instituto de Ciências Humanas, Universidade Federal de Pelotas, 2015. 124p.

SERVIÇO GEOLÓGICO DO BRASIL (CPRM). Geologia e Recursos Minerais do Estado do Rio Grande do Sul. Porto Alegre, 2008. 1 CD. Escala 1:750.000.

SANTOS, D. S.; DIAS, F. F. Uso de Anaglifos como Alternativa para Práticas de Estereoscopia em Sensoriamento Remoto. Anuário do Instituto de Geociências UFRJ, Niterói, v. 34, n. 2, 2011. P. 105 - 11.

SIMON, A. L. H. A dinâmica de uso da terra e sua interferência na morfohidrografia da bacia do Arroio Santa Bárbara - Pelotas (RS). DISSERTAÇÃO (Mestrado em Geografia) - Programa de Pós-Graduação em Geografia, Universidade Estadual Paulista "Júlio de Mesquita Filho". 2007. 187p.

TOMAZELLI, L. J.; VILLWOCK, J. A. O Cenozóico no Rio Grande do Sul: Geologia da Planície Costeira. In: HOLZ, M. \& DE ROS, L. E. (Orgs.) Geologia do Rio Grande do Sul. Porto Alegre: Centro de Investigação do Gondwana - Instituo de Geociências, UFRGS, 2000. P. 375 - 406.

VILLWOCK, J. A.; TOMAZELLI, L. J. Geologia Costeira do Rio Grande do Sul. Notas Técnicas; N 8; Dezembro de 1995. Centro de Estudos de Geologia Costeira e Oceânica, Instituto de Geociências, UFRGS. Porto Alegre/ RS, 1995. 45p. 